\title{
STUDI KASUS PENOLAKAN PUBLIK ATAS KEBIJAKAN PUBLIK
}

\author{
Rosmala Dewi* \\ Program Studi Administrasi Publik, Fakultas llmu Sosial dan llmu Politik \\ Universitas Medan Area, Indonesia
}

Diterima Februari 2017; Disetujui April 2017; Dipublikasikan Juni 2017

\begin{abstract}
Abstrak
Tujuan penelitian ini adalah untuk mengetahui publik dapat menerima kebijakan publik. Berdasarkan penelitian, beberapa kasus penolakan publik terhadap kebijakan publik antara lain peristiwa MALARI (Malapetaka Limabelas Januari) tanggal 15 Januari 1974, yang menolak kebijakan Presiden Soeharto yang dianggap terlalu tergantung kepada modal asing dan mengabaikan nasib rakyat kecil. Peristiwa tahun 1998 yang dipelopori mahasiswa di berbagai daerah, yang menuntut agar Presiden Soeharto turun dari kursi Presiden Rl yang dianggap publik tidak pro rakyat kecil. Selama beberapa tahun usia kemerdekaan Rl, kesejahteraan cenderung milik segelintir golongan masyarakat terutama yang menduduki jabatan strategis di pemerintahan, atau segelintir masyarakat yang memiliki kolega di pemerintahan. Demikian juga dengan peradilan, tajam ke bawah tapi tumpul ke atas. Kebijakan pemerintah menyikapi persoalan sosial tersebut acap kali tidak pro rakyat kecil sehingga rakyat melakukan perlawanan. Keberanian rakyat untuk melakukan perlawanan terhadap pemerintah semakin lama terkesan semakin anarkis dan brutal.
\end{abstract}

Kata Kunci : Penolakan, Kebijakan, Publik

This research aims to know the public can accept public policy. Based on the research, several cases of public rejection of public policy include the MALARI (Malapetaka Fifteen January) January 15, 1974, which rejected President Suharto's policy of over-reliance on foreign capital and neglected the fate of the common people. 1998 events pioneered by students in various regions, demanding that President Soeharto step down from the seat of the President of the Republic of Indonesia which is considered publicly not pro small people. For several years of Indonesian independence, welfare tended to belong to a handful of people, especially those who held strategic positions in government, or a handful of people with colleagues in government. Likewise with the judiciary, sharp down but dulled up. Government policy to address the social issue is often not pro small people so that people do resistance. The courage of the people to fight against the government increasingly seemed increasingly anarchic and brutal. The government must respond to the voice of the small people who promise to be promised during political campaigns during the Presidential and Pilk Regions. If the government remains indifferent to the various problems facing the public or the people, it is feared that the people will take a more anarchist fight.

Keywords: Disclaimer, Policy, Public

How to Cite : Dewi, R., (2017). Studi Kasus Penolakan Publik Atas Kebijakan Publik $5(1): 6-12$
${ }^{*}$ Corresponding author:
P-ISSN-2549-9165
E-mail: rosmaladewi@yahoo.com
e-ISSN -2580-2011 


\section{PENDAHULUAN}

Penolakan publik adalah suatu bentuk perlawanan oleh publik atau rakyat terhadap aturan-aturan yang ditetapkan pemerintah. Sedangkan kebijakan publik secara umum adalah arah tindakan yang mempunyai maksud yang ditetapkan oleh seorang aktor atau sejumlah aktor dalam mengatasi suatu masalah atau persoalan publik. Aktor-aktor dalam proses pembuatan kebijakan publik terdiri dari dua kelompok yaitu, aktor resmi seperti agen-agen pemerintah (birokrat), Presiden (eksekutif), DPR (legislatif) dan lembaga peradilan (yudikatif). Sedangkan aktor tidak resmi meliputi kelompokkelompok kepentingan seperti, partai politik dan warga negara di negara yang bersangkutan.

Semakin tinggi kesadaran publik terhadap hak dan kewajibannya, maka partisipasinya terhadap kebijakan publik akan semakin besar. Dalam negara yang menganut azas demokrasi, partisipasi publik terhadap kebijakan publik dapat dibedakan atas beberapa macam yaitu, 1) Partisipasi dalam pembuatan kebijakan publik. Dalam proses ini, masyarakat berpartisipasi aktif maupun pasif dalam pembuatan kebijakan publik. Misalnya memberikanmasukan atau pertimbangan baik secara lisan atau tertulis kepada pemerintah untuk menjadikan bahan pertimbangan dalam menentukan kebijakan publik sebelum ditetapkan, 2)Partisipasi dalam pelaksanaan.

Dalam hal ini publikturut melaksanakan program pemerintah, misalnya menjaga kebersihan lingkungan dengan tidak membuang sampah di sembarang tempat, menegakkan tertib lalu lintas dengan mematuhi aturan lalu lintas, dan lain-lain, 3) Partisipasi dalam memanfaatkan hasil. Dalam hal ini masyarakat dapat menikmati hasil pembangunan secara adil dalam arti mendapatkan pembagian sesuai dengan pengorbanan yang diberikan menurut peraturan perundang-undangan yang berlaku. Misalnya, hasil pembangunan jalan, pembangunan irigasi dan lain-lain, 4) Partisipasi dalam evaluasi. Dalam hal ini masyarakat diberi kesempatan untuk menilai hasil yang telah dicapai pemerintah. Partisipasi masyarakat dalam evaluasi dapat dilakukan dengan memantau hasil kebijakan publik dan pelaksanaannya.

Dengan demikian, penolakan publik dan kebijakan publik dapat diibaratkan bagai dua sisi mata uang. Tidak dapat dipisahkan, hanya dapat dibedakan. Kebijakan publik yang sesuai dengan keinginan publik tentu saja akan di dukung publik, sebaliknya kebijakan publik yang tidak sesuai dengan keinginan publik akan ditolak oleh publik, dan apabila penolakan publik terhadap kebijakan publik terjadi secara berulang-ulang, menjadi pertanda bahwa pemerintah mengabaikan aspirasi publik atau rakyatnya. Ada beberapa cara yang lazim dilakukan publik untuk menolak kebijakan publik antara lain adalah, melalui aksi demonstrasi, aksi pawai, mengadakan mimbar bebas, dan melakukan rapat umum.

\section{PEMBAHASAN}

Banyak para ahli memberikan pengertian kebijakan publik dengan beraneka macam pernyataan, walaupun pada intinya sama yaitu memiliki penekanan pada segala keputusan yang dibuat oleh pemerintah terhadap masalah yang sedang dihadapi dalam rangka pemenuhan kebutuhan-kebutuhan masyarakat yang beraneka ragam dan terus berkembang akibat dari tingkat pendidikan yang lebih tinggi yang diperoleh dan perkembangan teknologi.

Menurut Thomas R. Dye dalam Budi Wirano (2002 : 15 ) mengemukakan bahwa, kebijakan publik adalah apapun yang dipilih oleh pemerintah untuk dilakukan atau tidak dilakukan".

Selanjutnya Robert Eyestone dalam Wibawa, Samodra, Yuyun Purbokusumo dan Agus Pramusinto, (1994: 23) merumuskan kebijakan publik dapat didefenisikan sebagai hubungan suatu unit pemerintah dengan lingkungannya. Konsep yang ditawarkan sangat luas dan kurang pasti karena apa yang dimaksud dengan kebijakan publik dapat mencakup banyak hal".

Dengan demikian jelas bahwa, kebijakan publik pada umumnya dapat ditinjau dari dua perspektif yaitu dari perspektif analisis dan evaluasi kebijakan dan dari prespektif proses kebijakan. Perspektif pertama analisis dan evaluasi kebijakan itu sendiri mengandung dua hal yaitu analisis kebijakan dan analisis evaluasi. Dalam analisis kebijakan diharapakan akan ditemukannya alternatif-alternatif yang tepat dan sesuai, sehingga mampu mengatasi permasalahan yang sedang dihadapi sehingga tujuan yang diinginkan dapat tercapai. Evaluasi kebijakan memberikan penilaian atas masalah- masalah suatu kebijakan yang telah ditetapkan dan dilaksanakan dilihat 
dari sudut adequateness, affectiveness, appropriateness dan efficiency.

Prespektif kedua yaitu meliputi proses kebijakan yang menekankan pada perumusan, pelaksanaan, penilaian dan pengawasan. Edi Suharto, (2005 : 15), berkesimpulan penggabungan antara pollicy analysis dan policy proces dapat dikatakan sebagai policy cyclce, yang kemudian selanjutnya mengarah kepada terbentuknya suatu sistem kebijakan publik. Artinya dalam policy cycle itu mengandung beberapa tindakan ataupun tahap yang perlu ditempuh, yaitu : problem indentification ( Identifikasi masalah ), legitimation ( Perumusan ), implemation ( penerapan ), dan evaluation ( evaluasi ).

Pada tahap pertama yaitu identifikasi masalah, pemerintah dituntut untuk melakukan suatu tindakan berupa pemecahan masalah yang tepat dan sesuai. Adapun pengertian masalah publik itu sendiri tiada lain adalah kebutuhan atau ketidak puasan yang dimiliki oleh masyarakat perlu dicari cara - cara penanggulangannya, baik yang dilakukan oleh mereka yang secara langsung terkena akibat oleh masalah itu ataupun oleh orang lain yang mempunyai tanggung jawab untuk masalah itu. Masalah yang ada dalam masyarakat begitu luas oleh sifatnya yang heterogen, maka pemerintah tentunya tidak akan mampu untuk mengatasi semua masalah yang sedang dihadapi.

Dengan demikian pemerintah harus mampu untuk memilah - milah dan kemudian menetapkan prioritasnya terutama yang menyangkut masalah yang memiliki dampak yang luas dan sekaligus juga dampak terhadap individu yang tidak secara langsung terlibat. Dengan demikian maka masalah itu merupakan policy problem, dan selanjutnya menjadi suatu agenda pemerintah. Arifin Tahir (2014: 19) mengemukakan, agenda pemerintah itu adalah “ that set of items explicitly up for the active and serious consideration of outhoritative decisionmakers “. Artinya adalah serangkaian item -item yang secara tegas memerlukan pertimbangan yang aktif dan serius dari para pembuat keputusan yang sah berdasarkan prioritas dan tingkatnya.

Tahap berikutnya adalah legitimation process yang didalamnya mengandung berbagai kegiatan pilihan - pilihan, seperti mengidentifikasi pilihan, merumuskan pilihan, penilaian yang tersedia, dan akhirnya pemilihan alternatif yang terbaik. Selama merumuskan pilihan - pilihan yang dilakukan dalam proses ini harus bersifat objektif dan subjektif. Objektif artinya alternatif yang dipilih dapat memberikan dampak yang positif yang luas, sedangkan subjektif yaitu alternatif yang dipilih menyangkut aspek emosional dari pembuat kebijakan, masyarakat dan akhirnya dapat memberikan keuntungan bagi semua piihak.

Agar dapat membuat rumusan alternatif yang bersifat objektif dan subjektif, harus didukung oleh tersedianya kuantitas dan kualitas data yang akurat dan benar sehingga menjadikan suatu innformasi yang relevan dan aktual sifatnya yang dapat dipergunakan oleh para pembuat keputusan guna mengatasi masalah - masalah yang dihadapi. Informasi yang faktual, akurat dan relevan dapat memberikan masukan yang sangat berarti bagi para penganbil kebijakan dalam rangka penyelesaian perumusan. Pada saat perumusan telah dibuat, maka tahap berikutnya yang perlu dilakukan adalah bagaimana pelaksanaan kebijakan (policy implementation ) itu dilakukan dilapangan.

Pelaksanaan kebijakan itu merupakan kegiatan praktis dan konseptual seperti yang ditekankan dalam proses legitimasi. Dalam menerapkan kebijakan yang telah ditetapkan diperlukan adanya pengendalian ataupun pengawasan sepanjang waktu. Hal itu mengingatkan para pelaksana kebijakan pada tingkat bawah dalam kenyataannya sering mengalami kesulitan terhadap apa-apa yang telah menjadi keputusan yang sifatnya " given " dari tingkat atas, karena kebijakan yang dikeluarkan seringkali tidak tepat dengan kondisi sesungguhnya dilapangan. Atau bisa jadi karena kebijakan yang dikeluarkan belum dapat dimengerti benar oleh pelaksana secara komprehensip sehingga menjadi suatu problem sehingga mereka bergerak ke arah kepentingan organisasi, atau bahkan menjurus kepada kepentingan pribadi.

Disamping berorientasi pada kepentingan organisasi dan pribadi, dalam implementasinya para pelaksana kebijakan akan menjurus kepada suatu proses yang rumit dan berbelit- belit dan bahkan dianggap permulaan baru daripada seluruh proses kebijakan. Untuk mengatasi 
keadaan yang demikian itu maka diperlukan adanya komunikasi yang diberikan kepada pelaksana kebijakan tentang isi kebijakan yang sifatnya jelas, tepat, dan konsisten. Dengan tersedianya informasi yang jelas, akurat, dan konsisten tentang kebijakan tadi maka diharapak dapat membantu personil yang memiliki tanggung jawab tersebut dapat melaksanakan tugas dengan baik.

Hal ini baik, bukan saja dilihat dari faktor personil, melainkan pula dari efektivitas organisasi pemerintahan itu sendiri dalam rangka melaksanakan kebijakan itu, seperti : bagaimana pengorganisasiannya, struktur organisasi bersangkutan, pengalokasian dana yang tersedia adalah mutlak. Dengan demikian efektivitas organisasi yang telah dipersiapkan itu dalam rangka pelaksanaan kebijakan yang telah ditetapakn apakah dapat berjalan dengan semestinya, maka perlu dipelajari lebih jauh lagi melalui proses policy evaluation

Pada tahap akhir ini ( policy evaluation) adalah sangat diperlukan guna dapat memberikan suatu rekomendasi atau bahan kepada para pembuat kebijakan selanjutnya guna penyempurnaan kualitas kebijakan berdasarkan dari aspek positf maupun negatif atas pelaksanaan kebijakan yang telah berlaku.

Dalam proses ini selain bersifat evaluatif, tetapi juga harus bersifat empiris dan normatif. Evaluatif artinya menekankan pada makna atau nilai dari suatu kebijakan apakah sesuai dengan etika dan moral, dan dengan demikian jenis informasinya adalah evaluative. Normatif yaitu merupakan jenis informasi yang sifatnya mendukung ataupun dapat memberikan petunjuk ( advocative) yang berorientasi ke masa depan. Dengan demikian diharapkan dapat memberikan rekomendasi bentuk -bentuk tindakan yang bagaimana yang mungkin mampu memecahkan masalah - masalah publik.

Empirik menggambarkan sebab dan akibat dari kebijakan publik tertentu yang berlaku, dan dengan demikian jenis informasi yang dihasilkan adalah designative. Ketiga aspek tersebut sangat terikat sifatnya sehingga tidak ada salah satupun yang dapat berdiri sendiri. Dengan demikian rekomendasi yang dibuat akan bersifat holistic, dan pada akhirnya mampu memberikan gambaran yang jelas kepada pembuat kebijakan dalam rangka pengambilan keputusan yang tepat.
Kebijakan publik yang telah diputuskan bukanlah suatu akhir dari proses terhadap pemecahan masalah yang ada, akan tetapi hanyalah bersifat temporer mengigat perkembangan masyarakat yamng begitu cepat dan dinammis. Dengan demikian proses kebijakan publik tidak akan pernah berakhir tetapi minimal diharapkan mengarah kepada suatu perbaikan kualitas hidup masyarakat yang lebih baik lagi.

Hal ini-pun tidak terlepas dari kebijakan publik yang telah dikeluarkan pemerintah tentang pendidikan dan pelatihan bagi jabatan Eselon 111. Mengingat perkembangan llmu pengetahuan dewasa ini khususnya tentang kajian kepemimpinan dan manajemen yang mana merupakan inti daripada kebijakan dimaksud, sudah barang tentu perlu dilakukan evaluasi kembali apakah masih relevan atau tidak. Sebaliknya re-evaluation perlu dilakukan terhadap program pendidikan dan pelatihan pada level ini sebagai tindak lanjut dari kebijakan dimaksud. Untuk itu maka perlu sekali ditinjau secara teoritis baik tentang pemdidikan dan pelatihan maupun dari aspek kepemimpinan dan manajemen sehingga akan mampu memberikan rekomendasi terhadap perbaikan kurikulum pendidikan dan pelatihan dan juga terhadap kebijakan publik itu sendiri di masa mendatang.

Umumnya kota-kota besar di Indonesia menghadapi permasalahan pokok terutama dalam bidang, tingginya tingkat polusi udara, kriminalitas, membuang sampah sembarangan dan kemacetan lalu lintas. Warga yang mengendarai kenderaan menuju tempat pekerjaannya dan sebaliknya pulang ke rumah, dihadapkan kepada persoalan kemacetan lalu lintas. Disamping persoalan lalu lintas juga dibarengi dengan polusi udara yang berasal dari knalpot kenderaan pengguna jalan. Persolan kemacetan dan polusi udara tentu bukanlah peristiwa yang terjadi begitu saja, melainkan diakibatkan oleh apa yang sering kita sebut dengan "Kebijakan Publik".

Berbagai kebijakan yang dikeluarkan pemerintah, menekankan pembangunan jalanjalan besar, membantu menekan rendah tingkat harga Bahan Bakar Minyak (BBM), namun pada sisi yang lain juga nampak kurangnya perhatian terhadap system pengangkutan umum. Apakah kebijakan-kebijakan lain telah menghasilkan system transportasi yang lebih memuaskan masih 
terbuka untuk diperdebatkan, namun demikian yang menjadi persoalan pokoknya adalah kemacetan lalu lintas dan polusi udara di beberapa kota besar di Indonesia hingga kini bukanlah yang terjadi secara alamiah, tetapi kebijakan publik telah menyebabkan banyak hal yang membentuk situasi perkotaan seperti yang terjadi sekarang ini.

Kebijakan sangat besar pengaruhnya bagi penghidupan manusia, oleh sebab itu perlu dicari upaya untuk mendorong perubahan kebijakan dan hukum yang lebih berpihak kepada masyarakat. Dalam konteks ini terdapat beberapa upaya yang umum dilakukan yaitu:

1. Penyediaan informasi untuk mendukung kebijakan dan praktik pembangunan yang berpihak kepada masyarakat miskin. Pendalaman dan penguatan hubungan antara kelompok masyarakat miskin dengan kelompok elit pembuat kebijakan.

2. Mendukung proses partisipatif dalam perumusan di semua tingkatan.

3. Meningkatkan keterbukaan dan tanggung jawab dari pengambil keputusan publik (salah satu tujuan penting desentralisasi; memisahkan fungsi penyediaan pelayanan, fungsi pengaturan dan fungsi pendanaan).

4. Membantu perencanaan, penyusunan peraturan dan pelaksanaan perundangundangan yang penting bagi masyarakat miskin.

5. Mendorong penerapan kebijakan redistribusi dan menyediakan jaring pengaman sosial yang secara langsung menguntungkan kelompok masyarakat miskin.

6. Mengembangkan pasar yang adil dan kompetitif.

7. Menyediakan dukungan bagi organisasi setempat untuk menerapkan proses dan tata laksana yang berpihak kepada masyarakat miskin.

8. Meningkatkan efektivitas proses pengambilan keputusan (mengurangi resiko, mengefektifkan regulasi dan memastikan proses yang adil dan lainlain).
Kebijakan tentunya memiliki pengaruh langsung terhadap pencapaian penghidupan masyarakat, perasaan tidak terpinggirkan dan aspek kesejahteraan secara umum. Kebijakan akan senantiasa dapat kita saksikan di tengah-tengah masyarakat, mulai dari individu, keluarga, masyarakat hingga dunia internasional. Contoh kebijakan yang dapat mempengaruhi penghidupan masyarakat adalah:Nilai perumahan dipengaruhi oleh keberadaan penyediaan air, listrik, pembuangan sampah dan pengaturan pemerintahan terfhadap penyediaan jasa-jasa tersebut. Nilai perumahan pada suatu lokasi juga mungkin dipengaruhi oleh kepercayaan, budaya atau adat. Nilai lahan dipengaruhi oleh kebijakan dan hukum di bidang pertanian, lingkungan hidup, eksport-import, pemasaran dan lain-lain.

Dengan demikian jelas bahwa, kebijakan memiliki pengaruh yang luas bagi penghidupan masyarakat, oleh karena itu penting untuk memahami hubungan dan keterkaitan antara kebijakan, individu dan kelompok masyarakat. Dalam hal ini, institusi pemerintah dapat dijadikan sebagai konteks analisa, yang mana dari sinilah bermula berbagai praktik pembangunan yang dilakukan pemerintah, kebijakan, aturan, peran dan fungsi organisai-organisasi yang lain baik pemerintah maupun non pemerintah dalam menyelenggarakan pelayanan bagi seluruh lapisan masyarakat.

Suatu kebijakan dapat memiliki pengaruh yang luas bagi kehidupan masyarakat baik secara langsung maupun secara tidak langsung. Untuk memahami bagaimana suatu proses, termasuk kebijakan mempengaruhi penghidupan masyarakat perlu ditelusuri secara lebih mendalam, tidak saja mengenai dampak yang terjadi akan tetapi termasuk juga bentuk dan sifat kebijakan itu sendiri.

Bagaimana suatu analisa proses dilaksanakan dapat mengacu kepada berbagai metode analisa kebijakan yang telah ada, atau dapat pula dikembangkan metode yang lebih sederhana agar memungkinkan masyarakat luas turut serta di dalamnya.Analisa kebijakan; peraturan dan perundang-undangan yang berlaku membutuhkan informasi dan telaah terhadap beberapa hal antara lain:

1. Apa yang dimuat dan diamanatkan dalam dokumen tertulis? 
2. Apa yang diharapkan oleh suatu kebijakan dan peraturan-peraturan pendukung yang berkaitan?

3. Bagaimana kenyataannya dalam praktik ?.

Dengan demikian, sebelum kebijakan ditetapkan harus terlebih dahulu melalui proses perencanaan yang matang. Demikian juga dengan kebijakan yang sudah ditetapkan meski konten atau isinya sudah baik namun apabila tidak dilaksanakan, akan percuma atau sia-sia tanpa memberikan efek positif bagi pemerintah dan masyarakat.

Aksi demonstrasi merupakan cara-cara yang paling diminati rakyat untuk meyampaikan pendapat dimuka umum yang dilakukan secara demonstratif, atraktifdan menarik. Sedangkan aksi pawai merupakan bentuk penolakan kebijakan publik yang dilakukan secara bersama-sama oleh beberapa orang dengan cara berpindah tempat dari satu tempat ke tempat lainnya baik dengan berjalan kaki maupun dengan menggunakan kenderaan secara tertib, sementara cara penolakan kebijakan publik dengan mimbar bebas adalah cara penyampaian sikap melalui orasi pada tempat-tempat tertentu atas penolakan mereka terhadap kebijakan publik tersebut, sedangkan penolakan melalui rapat umum adalah bentuk kegiatan dengan melakukan rapat oleh berbagai elemen masyarakat untuk menyampaikan keberatan atau penolakan atas kebijakan publik yang ditetapkan pemerintah.

Beberapa kasus penolakan publik terhadap kebijakan publik yang sempat menggegerkan stabilitas nasional, antara lain adalah peristiwa MALARI (Malapetaka limabelas januari) yaitu sebuah aksi demonstrasi mahasiswa dan kerusuhan sosial tanggal 15 Januari1974, yang menolak kebijakan Presiden Soeharto yang dianggap terlalu tergantung kepada modal asing dan mengabaikan nasib rakyat kecil. Peristiwa yang hampir sama, juga terjadi tahun 1998 yang dipelopori mahasiswa di berbagai daerah, yang menuntut agar Presiden Soeharto turun dari kursi Presiden Rl yang dianggap publik tidak pro rakyat kecil.

Sikap pemerintah yang mengabaikan nasib rakyat kecil tentu sangat bertentangan dengan bunyi Pasal 34 ayat (2) UUD 1945 bahwa, "Negara mengembangkan sistem jaminan sosial bagi seluruh rakyat dan memberdayakan masyarakat yang lemah dan tidak mampu sesuai dengan martabat kemanusiaan". Memaknai isi pasal 34 ayat (2) UUD 1945 tersebut, selama beberapa tahun usia kemerdekaan Rl, kesejahteraan hanya milik segelintir golongan masyarakat terutama yang menduduki jabatan strategis di pemerintahan, atau segelintir masyarakat yang memiliki kolega di pemerintahan. Demikian juga dengan peradilan, hanya tajam ke bawah tapi tumpul ke atas. Kebijakan pemerintah menyikapi persoalan sosial tersebut acap kali tidak pro rakyat kecil sehingga rakyat melakukan perlawanan. Keberanian rakyat untuk melakukan perlawanan terhadap pemerintah semakin lama terkesan semakin anarkis dan brutal.

Seiring langsengnya Soeharto dari kursi Presiden Rl setelah berkuasa lebih kurang 32 tahun, dimulailah babak baru dalam peta politik Indonesia yang lazim disebut era reformasi. Era reformasi yang digadang-gadang dapat membawa perubahan nasib rakyat ke-arah yang lebih baik, ternyata hingga 19 tahun usianya belum membawa angin segar. Justru sebaliknya tingkat kemiskinan, pengangguran, kejahatan dan beberapa masalah sosial semakin kentara. Beberapa kebijakan pemerintah yang dianggap extrim dan tidak pro rakyat seperti, kenaikan harga Bahan Bakar Minyak (BBM), kenaikan Tarif dasar Listrik (TDL), Standar Upah Minimum Regional (UMR), fluktuasi nilai rupiah terhadap Dollar dan lain-lain. Kebijakan ini ditentang dan dikritisi oleh rakyat dengan cara melakukan aksi demonstrasi. Terkait dengan merosotnya nilai tukar rupiah terhadap dollar telah menyebabkan harga sembako melambung tinggi. Kenaikannya bisa terjadi 2-3 kali dalam satu bulan, inflasi semakin tinggi tanpa dapat dikendalikan oleh pemerintah yang terlihat pasrah dan berkilah mengikuti hukum ekonomi pasar karena ngotot ingin menghilangkan subsidi.

\section{SIMPULAN}

Di sejumlah daerah seperti Solo, Yogjakarta, Bogor, Jakarta, Medan, Bandung, Surabaya dan lainlain sudah muncul reaksi unjuk rasa terhadap ketidakberdayaan pemerintah Jokowi-jK menstabilkan harga kebutuhan pokok, politik dibuat gonjang-ganjing, hukum diramaikan dengan perseteruan dan pengkriminalisasian KPK, pemberantasan KKN mati suri. Dari berbagai 
kegagalan pemerintah menyahuti suara rakyat kecil yang getol dijanjikan sewaktu kampanye politik pada saat Pilpres maupun Pileg, Selain itu, rakyatpun semakin apatis, tidak merasa memiliki atas masa depan negeri ini. Apabila, pemerintah tetap acuh dengan berbagai persoalan yang dihadapi publik atau rakyat, dikhawatirkan rakyat akan melakukan perlawanan yang lebih anarkis.

Demikian juga dengan gelora amarah yang datang secara bersahutan dari berbagai daerah, tentu saja akan dapat mengancam integritas bangsa. Oleh karenanya, untuk membangun pemerintahan yang baik disarankan agar pemerintah lebih pro aktif mendengar dan menyahuti keinginan rakyat.

\section{DAFTAR PUSTAKA}

Suharto, Edi, 2005, Analisis Kebijakan Publik, Alfabeta, Jakarta.

Tahir, Arifin, 2014, Kebijakan Publik \& Transparansi Penyelenggaraan Pemerintah Daerah, Alfabeta, Bandung.

Wibawa, Samodra, Yuyun Purbokusumo dan Agus Pramusinto, 1994, Evaluasi Kebijakan Publik, Raja Grafindo Persada, Jakarta.

Winarno, Budi, 2002, Teori dan Proses Kebijakan Publik, Media Pressindo, Yogjakarta. 